Georgia State University

ScholarWorks @ Georgia State University

$5-2-2013$

\title{
Licensure and Worker Quality: A Comparison of Alternative Routes to Teaching
}

Tim R. Sass

Georgia State University, tsass@gsu.edu

Follow this and additional works at: https://scholarworks.gsu.edu/uwrg_workingpapers

\section{Recommended Citation}

Sass, Tim R., "Licensure and Worker Quality: A Comparison of Alternative Routes to Teaching" (2013). UWRG Working Papers. 136.

https://scholarworks.gsu.edu/uwrg_workingpapers/136

This Article is brought to you for free and open access by the Usery Workplace Research Group at ScholarWorks @ Georgia State University. It has been accepted for inclusion in UWRG Working Papers by an authorized administrator of ScholarWorks @ Georgia State University. For more information, please contact scholarworks@gsu.edu. 


\section{W. J. Usery Workplace Research Group Paper Series}

Working Paper 2013-5-2

May 2013

\section{Licensure and Worker Quality: A Comparison of Alternative Routes to Teaching}

Tim R. Sass

Georgia State University 


\title{
LICENSURE AND WORKER QUALITY: A COMPARISON OF ALTERNATIVE ROUTES TO TEACHING*
}

\author{
Tim R. Sass \\ Department of Economics \\ Georgia State University
}

May 28, 2013

\begin{abstract}
In this paper I use a rich longitudinal data base from Florida to compare the characteristics of alternatively certified teachers with their traditionally prepared colleagues. I then analyze the relative effectiveness of teachers who enter the profession through different pathways by estimating "value-added" models of student achievement. In general, alternatively certified teachers have stronger pre-service qualifications than do traditionally prepared teachers, with the least restrictive alternative attracting the most qualified prospective teachers. Of the three alternative certification pathways studied, teachers who enter through the path requiring no coursework have substantially greater effects on student achievement than do either traditionally prepared teachers. In contrast, the alternative pathway that requires substantial occupation-specific human capital investment yields the least effective teachers. These results suggest that any benefits from pre-service training are overwhelmed by the adverse selection into programs that require non-transferable human capital investments.
\end{abstract}

\footnotetext{
"Previous versions were circulated under the title "Certification Requirements and Teacher Quality: A Comparison of Alternative Routes to Teaching." I wish to thank the staff of the Florida Department of Education's Education Data Warehouse and the Office of Teacher Certification for their help in obtaining and interpreting the data used in this study. Thanks also go to Micah Sanders for able research assistance and to Jeanne Burns, Stuart Elliot, Cory Koedel, George Noell, Steve Rivkin, Jake Vigdor, Jim Wyckoff and seminar participants at the University of Missouri for valuable conversations and suggestions. This research was funded in part by the National Center for the Analysis of Longitudinal Data in Education Research (CALDER). CALDER is supported by the Institute for Education Sciences Grant R305A060018. Any opinions or errors are solely attributable to me, however.
} 


\section{Introduction}

Workers in licensed occupations make up a large and growing proportion of the U.S. workforce, with nearly three out of ten U.S. workers being required to hold a license in order to do their job (Kleiner and Krueger (2010)). There are two opposing views for the prevalence of licensure. In the "public interest" approach, licensing is viewed as a mechanism for ensuring quality when consumers are poorly informed. By setting minimum quality standards, licensure indirectly provides consumers information and avoids the classic "lemons problem" whereby consumers' inability to distinguish quality differences leads to only low quality practitioners in the market (Akerlof (1970), Leland (1979)). The public interest approach implies that professional licensure would be most likely to occur where the cost to consumers of obtaining information is high and the loss from consuming low quality services is great. Consumers who value improvements in service quality highly will benefit from licensure, while consumers who prefer lower quality (at a lower price) could be made worse off (Shapiro (1986)). In contrast, the "capture" theory of regulation posits that professionals will seek out licensure as a means of restricting entry into a profession, thereby raising wages (Stigler (1971), Peltzman (1976)). Under this scenario consumers face higher service prices and reductions in quantity with no concomitant increase in service quality, leaving consumers unambiguously worse off.

Empirical analysis of the effects of licensure has been hampered by two factors. First, most studies rely on cross-state comparisons in order to generate identifying variation in licensure restrictiveness. This is problematic because it is difficult to account for other state-level factors that may be correlated with both the extent of regulation and outcomes of interest like wages or employment. Second, it is often difficult to measure the quality of output, which has led to a paucity of studies which directly gauge the impact of licensure on the quality of services provided. 
In order to overcome the dual hurdles of within-state variation in licensure regulations and measurement of service quality I analyze the multiple pathways by which a person can be licensed to teach in the State of Florida. ${ }^{1}$ Florida has one of the most diverse set of routes to licensure for teachers, with wide variation in human capital attainment requirements. It is also one of the few places in which data exist to link individual teachers to their own pre-service educational records as well as to the performance of students they subsequently teach, thereby creating multiple ways in which provider quality can be measured.

Besides the data advantages inherent in studying the pathways to licensure for teachers, there are many policy-relevant rationale for analyzing the licensure of teachers. First, teaching is the licensed occupation with the largest number of workers (Kleiner (2000)). Second, there is intense interest in improving educational outcomes for students and research has demonstrated that the most important school-based determinant of student achievement is teacher quality (Rivkin, Hanushek and Kain (2005), Aaronson, Barrow and Sander (2007), Kane, Rockoff and Staiger (2008). Third, there is little evidence that training or incentives received after becoming a teacher leads to improvements in teacher performance (Garet, et al. (2008), Garet, et al. (2010), Harris and Sass (2011), Jacob and Lefgren (2004), Springer, et al. (2010), Springer, et al. (2012), Glazerman and Seifullah (2012)), which suggests that altering the quality of new teachers is a crucial policy lever. Finally, the number of teachers entering the profession through means other than the traditional route of completing a university-based program in

\footnotetext{
${ }^{1}$ In the economic literature "licensure" refers to regulations that prohibit workers who do not meet specific criteria, such as passing an exam and/or completing an approved course of study, from legally working. In contrast, "certification" refers to the situation where workers who meet certain criteria are given a designation of being certified, but non-certified individuals are also allowed to offer their services in the market. The least restrictive form of occupational regulation is registration, whereby individuals file information on their qualifications, but there are no specific requirements for professional standing or limitations on who may practice. In education the term "certification" refers to state statutes that set out requirements that must be met for an individual to teach on a permanent basis and is thus equivalent to the economic concept of licensure. For consistency, I will use the term licensure throughout.
} 
teacher education has been rapidly expanding. In 1985/86 less than 300 teachers in the United States obtained licensure through routes other than completing a traditional teacher preparation program. Two decades later, in 2005/06, the number of teachers who became licensed through alternate routes mushroomed to $59,000 .^{2}$ This rapid rise in alternative routes to licensure begs the question of how do these alternative-route teachers perform relative to their traditionally prepared colleagues.

I begin by briefly reviewing the empirical literature on licensure and worker quality, including a discussion of research on alternative routes to teaching. I then outline a theoretical framework that is used to motivate the empirical work. Next, I describe the teacher licensure environment in Florida and the available data. The analysis of the data proceeds in two steps. First, I provide descriptive statistics on the pre-service education, demographics and test performance of teachers by the route they take to certification. In the second part of the analysis I estimate cumulative achievement functions in order to determine the relative productivity or "value-added" of teachers who obtain certification by completing a traditional teacher preparation program vis-à-vis various alternative routes.

\section{Existing Evidence of the Effects of Licensure on Quality}

\section{A. Occupations Other Than Teaching}

While there is a large empirical literature on the effects of licensure, most of the extant research investigates wage and employment effects. ${ }^{3}$ There is relatively little evidence of the impact of licensing restrictions on the quality of licensed professionals and the services they provide. Of the few extant studies, most utilize relatively crude proxies for quality, such as numbers of consumer complaints or

\footnotetext{
${ }^{2}$ See "Overview of Alternate Routes to Certification" at http://www.teach-now.org/overview.cfm.

${ }^{3}$ For reviews of the empirical literature on occupational licensing, see Gaumer (1984), Kleiner (2000), Stephenson and Wendt (2009), Ramseyer and Rasmussen (2012) and Larsen (2013).
} 
numbers of accidents, or rely on indirect connections between the quality of services received and the licensed professionals who provided the services. Maurizi (1980) investigates the licensing of contractors in California and finds that increases in the number of consumer complaints are correlated with the rise of exam preparation schools which allegedly weakened the licensure system by increasing the ability of incompetent or poorly trained contractors to pass the licensure exam. Carroll and Gaston (1981), employing a cross-section of data on the 50 states, find licensing restrictions are associated with fewer journeyman electricians and the corresponding reduction in the density of electricians is associated with a higher number of accidental deaths by electrical shock. Similarly, when comparing dental licensing across states they find that imposing citizenship requirements for licensure of dentists is associated with a reduction in number of dentists per capita which in turn is correlated with longer wait times for appointments. Johnson and Loucks (1986), also using cross-sectional state-level data, find reductions in the number of real estate agents per capita are associated with a fall in the number of complaints per transaction. However, neither pass rates on the licensure exam or continuing education requirements are correlated the frequency of consumer complaints.

In contrast to earlier work, the two most recent studies employ micro-level data to explore the relationship between licensure restrictions and service quality. Kleiner and Kudrle (2000) analyze the results of dental exams given to nearly 500 Air Force recruits. Using survey information they link recruits to dental licensure requirements in the recruits' prior state of residence. Controlling for a number of intervening factors, like parents' education and income, prior dental insurance coverage and access to fluoridated water, they find no association between recruits' present state of dental health and the dental licensing environment where the recruits grew up. Currie and Hotz (2004) employ individuallevel data from the National Longitudinal Survey of Youth and Vital Statistics mortality records to investigate the impact of day care center licensure requirements on the incidence of accidental injuries. 
To avoid possible bias from endogenous regulations, they employ state fixed effects or child-specific fixed effects. They find that increases in the minimum education requirement for day care center directors (which tend to be correlated with educational requirements for teachers and aides) significantly reduce the risk of unintentional injuries. More restrictive regulation also tends to reduce the use of day care centers and pre-schools and increase the use of informal child care providers, presumably by raising the cost of formal providers. Given that informal care tends to be less safe, this indirect effect could partly offset any safety gains from more stringent regulation.

\section{B. Specific Licensure Requirements and Teacher Quality}

A trio of studies investigates the effects of educational and testing requirements on the quality of teachers. In the earliest work, Berger and Toma (1994) analyze the relationship between educational requirements for teachers and scores on the Scholastic Achievement Test (SAT) with a panel of statelevel data. Holding constant a variety of state-level policy and demographic variables, they find that requiring teachers to hold a master's degree is associated with a significant reduction in SAT scores. Angrist and Guryan (2008) use school district level data from the Schools and Staffing Survey (SASS) to compare testing requirements to the qualifications of teachers. They find no evidence that the incidence of state testing requirements for teachers are associated with the selectivity of the institutions that early-career teachers graduated from (based on average SAT scores of entering freshman and research university designation). Most recently, Larsen (2013) combines the approaches of Berger and Toma and Angrist and Guryan and measures the impact of testing requirements on both student test scores and on teacher qualifications. Like Angrist and Guryan he uses data from SASS and measures teacher input quality by the average SAT scores of entering students at the undergraduate institution a teacher attended. Output quality is measured by individual-level 8 th grade scores on the National Assessment of Educational Progress (NAEP). For his sample of 259 first-year teachers, neither subject 
area, basic-skill or professional knowledge test requirements have an impact on input quality. However, requiring a test of subject-area knowledge for licensure is associated with a significant increase in average input quality of all teachers (2,277 teachers in total). Among first-year teachers, requiring teachers to take a subject-area test is associated with a decrease in the upper tail of input quality, suggesting that the exam requirement may dissuade the most talented individuals from entering teaching. However, these distributional effects do not carry over when analyzing the effects on student NAEP scores.

\section{Traditional vs. Alternative Routes to Teaching}

While prior research on various aspects of teacher preparation dates back to the 1960s (Wilson, Floden and Ferrini-Mundy (2001)), only recently has there has there been rigorous quantitative research that compares the effectiveness of teachers who complete traditional teacher preparation programs to those who enter teacher through alternative routes. Two recent quasi-experimental studies, Boyd, et al. (2006) and Kane, Rockoff and Staiger (2008), examine elementary and middle school teachers in New York City. In New York City alternative routes involve the same requirements as the traditional teacher preparation program pathway, but entrants are allowed to begin teaching after 200 hours of pre-service training and passage of the requisite teacher exams. The alternative-route teachers must then enroll in teacher education programs and complete the coursework required for certification while they are teaching.

Boyd et al. focus their analysis on the two primary alternative pathways in New York City, the NYC Teaching Fellows program (Fellows) and the Teach for America program (TFA). These programs target different types of potential teachers. The TFA program recruits graduates of elite colleges and universities to teach in high-poverty schools. In contrast, the Fellows program is designed to attract both mid-career professionals and recent college graduates into teaching. 
When using student covariates to control for student heterogeneity, Boyd et al. find that Fellows are less effective in teaching both math and ELA than traditionally prepared teachers. When student fixed effects are added to the model, however, the difference in math effectiveness is no longer statistically significant and the ELA effectiveness differential is cut in half, suggesting that Fellows are more likely to teach in classes with lower achieving students. Boyd et al. also find that Fellows tend to improve over time relative to their traditionally prepared colleagues. In the elementary grades Fellows are initially less effective but by their third year are equally as effective as traditional route teachers. At the middle school level, Fellows in their third year of teaching are actually more effective in both math and English-Language Arts (ELA).

TFA teachers tend to be stronger in teaching math than Fellows, though follow similar patterns with respect to experience and grade level of instruction. Combining grades 4 through 8 and using student covariates to control for student heterogeneity, TFA teachers are just as effective as traditionally prepared teachers in math but less effective than teacher preparation program completers in ELA instruction. These results are unchanged when student fixed effects are used to control for observed and unobserved student characteristics. The effectiveness differential in ELA is driven primarily by results for rookie teachers; after the first year, TFA teachers and traditionally-prepared teachers are equally effective in teaching ELA. There are also interesting cross-grade differences as well. TFA middleschool math teachers actually appear more effective in their first year than traditionally prepared middleschool math teachers. In contrast, the lower effectiveness of first-year TFA teachers, relative to traditionally prepared teachers, is observed at both the elementary and middle school levels.

Kane, Rockoff and Staiger perform a similar analysis, but possess an additional year of data and can thus produce more precise estimates of the effectiveness of alternatively certified teachers, particularly those with more than two years of experience. They find no difference between the 
effectiveness of Fellows and traditionally prepared teachers in math. Fellows are slightly less effective in ELA instruction initially, but close the gap by their third year of teaching. TFA teachers are found to be more effective than traditionally prepared teachers in math, but no different in ELA instruction.

The TFA program is distinctive in that it targets new college graduates, participants commit to teaching for two years and they are typically assigned to schools with a high proportion of students living in poverty. All of these factors would tend to lead to high attrition rates as many TFA teachers may view participation as a short-term public service, rather than initiation of a long-term career. Both Boyd et al. and Kane, Rockoff and Staiger find evidence supporting these expectations. Boyd et al. find that after their requisite two years of service, attrition among TFA teachers is more than double that of traditionally prepared teachers. Even when adjusting for school quality, the four-year cumulative attrition rate among TFA teachers is nearly twice that of traditionally prepared teachers. Kane, Rockoff and Staiger estimate the differential attrition leads to a steady state where 45 percent of TFA teachers are in their first or second year whereas only 20 percent of traditionally prepared teachers are rookies or second-year teachers. Since teacher effectiveness increases with early-career experience, the high attrition rate tends to mitigate any gains from employing TFA teachers. Kane, Rockoff and Staiger estimate that the greater effectiveness of TFA teachers in mathematics (relative to traditionally prepared teachers) is essentially offset in the steady state by the higher attrition rate of TFA teachers.

Another recent quasi-experimental study, Xu, Hannaway and Taylor (2011), studies the performance of TFA teachers at the high school level in North Carolina. Using school effects and crosssubject student fixed effects to control for non-random assignment of teachers to schools and classrooms within a school, they find that TFA teachers generally out-perform their traditionally prepared colleagues. If one takes into account the fact that TFA teachers generally possess less experience than traditionally-prepared teachers, TFA teachers boost student achievement by 13 percent of a standard 
deviation, averaged over all subjects. In math the difference in student learning is also 13 percent of a standard deviation and for science it is 19 percent of a standard deviation, suggesting a smaller effect for subjects like English. When experience is not controlled, the differential in math is reduced by more than half and is statistically insignificant, but it science the differential only falls slightly, to 16 percent of a standard deviation, and is significantly different from zero.

Two teams of researchers from Mathematica have conducted experimental evaluations of alternative certification programs. Glazerman, Mayer and Decker (2006) compare TFA teachers with traditionally prepared teachers teaching in the same grade and school where students were randomly assigned to classrooms. The evaluation was conducted in 17 schools spanning 6 geographic areas. Their results are strikingly similar to those of Xu, Hannaway and Taylor. Glazerman, Mayer and Decker find TFA teachers outperform traditionally prepared teachers in math by 15 percent of a standard deviation, but the difference in reading achievement is not significantly different from zero. As in Xu, Hannaway and Taylor, the differential in teacher effectiveness was larger when TFA teachers are compared to traditionally prepared teachers with similar experience.

Like Glazerman, Mayer and Decker, Constantine, et al. (2009) compare outcomes for pairs of teachers in the same grade and school in which classroom assignment was random. However, rather than analyze TFA teachers, Constantine et al. study less selective alternative certification programs with data from 63 schools in 20 school districts. Alternative certification programs were divided into two categories, those requiring relatively less coursework (75-274 hours) and those requiring more coursework (275-795). Thus both groups still received considerable formal training in education. In contrast to the selective TFA program, the alternative certification teachers studied by Constantine et al. were no different than traditionally prepared teachers in terms of the selectivity of the college they attended or their scores on college entrance exams. The study found no significant differences in 
effectiveness between alternative and traditionally prepared teachers or between alternatively certified teachers with "high" and "low" coursework requirements. Similarly, the content of pre-service coursework or receipt of a bachelor's degree in education was uncorrelated with teacher effectiveness. While the results certainly cast doubt on the notion that traditional teacher programs boost the productivity of classroom teachers, the implications must be tempered by the fact that the alternatively certified teachers in fact had substantial coursework in education prior to becoming teachers.

\section{Theoretical Framework}

As in many other professions, there are two components to the licensure of teachers in most states. First, there is a minimum educational requirement. Traditionally teachers had to complete a teacher preparation program at a college or university, receiving a bachelor's degree in a specific field of education. Most alternative routes still require attainment of a bachelor's degree, but do not require a particular major. Second, most states also require passage of one or more examinations for a teacher to become fully certified. The exam requirements typically apply to both traditionally prepared and alternatively certified teachers.

The effect on teacher quality of loosening educational requirements depends on which theory of regulation holds sway. If teacher licensure serves to promote quality by requiring coursework that makes teachers more effective, then alternatively certified teachers, who are not required to take as many education courses as traditionally prepared teachers, should be less productive. If licensure is primarily motivated by capture, then alternatively certified teachers would be of equal or even higher quality than traditionally prepared teachers. Lott (1996) argues that minimum educational requirements could actually reduce quality by differentially raising the cost of licensure to the most talented potential 
entrants into a profession. For example, in the education context, potential teachers working in other occupations may be discouraged from entering teaching because of the high opportunity cost of taking required coursework before being certified to teach. Likewise, undergraduates who possess talents in non-educational fields may find requirements mandating numerous education courses that do not produce transferable skills particularly burdensome.

To formalize these notions regarding the impact of varying educational requirements embodied in traditional and alternative routes to teacher licensure, I adapt the licensure testing model of Ramseyer and Ramussen (2012). The population of potential teachers (which for parsimony are called "students") has ability $x$ where $x \sim \mathrm{U}(0,1)$. Initially there is a single pathway to licensure which requires a student complete a course of study of length $\ell$ and pass an exam. The probabilities of completion and passage are denoted $\mathrm{p}_{\mathrm{c}}$ and $\mathrm{p}_{\mathrm{p}}$. Both the probability of successful course completion and exam passage are increasing functions of ability, $x$. Assuming that training provides some valuable knowledge, $\mathrm{p}_{\mathrm{p}}$ is also increasing in $\boldsymbol{\ell}$. Costs of completing a course of study, $\mathrm{C}_{\mathrm{c}}$, are primarily time costs. Assuming that the opportunity cost of lost wages rises with ability, then course completion costs can be denoted as $\mathrm{c}_{\mathrm{c}}(x, \ell)$ with $\partial \mathrm{c}_{\mathrm{c}} / \partial x>0$ and $\partial \mathrm{c}_{\mathrm{c}} / \partial \boldsymbol{l}>0$. I further assume that the marginal cost of completion is non-decreasing in ability, so $\partial^{2} c_{c} / \partial x^{2} \geq 0$ There is a fixed cost to taking the exam that is independent of ability, $c_{p}$. The value of obtaining a license to teach is w. A student's expected payoff from entering the pathway to licensure is thus:

$\pi(x)=\left[p_{c}(x) \cdot p_{p}(x, \ell) \cdot w\right]-\left[c_{c}(x, \ell)+c_{p}\right]$

Any student for which $\pi(x)>0$ will enter the pathway for teaching. The first bracketed term is the expected gain from taking the pathway to licensure and the second bracketed term is the total cost. For a given length of study, $\ell_{0}$, denote the expected gain and total cost as $\mathrm{B}_{0}$ and $\mathrm{C}_{0}$ respectively. Denote by 
that $\underline{x}_{0}$ and $\bar{x}_{0}$ the lowest and highest ability types taking the test, i.e. $\pi\left(\underline{x}_{0}\right)=0$ and $\pi\left(\bar{x}_{0}\right)=0$. I assume that there are some low-ability and some high ability students who do not choose the pathway, so that $\underline{x}_{0}>0$ and $\bar{x}_{0}<1$. The situation is illustrated in Figure 1 .

As noted above, pathways generally vary in terms of the extent of required coursework, $\mathrm{c}_{\mathrm{c}}$. The effect of an increase in required coursework is

$\left.\partial \pi(\mathrm{x}) / \partial \boldsymbol{l}=\mathrm{p}_{\mathrm{c}}(\mathrm{x}) \cdot \partial\left[\mathrm{p}_{\mathrm{p}}\left(\mathrm{x}, \boldsymbol{\ell}_{\mathrm{k}}\right)\right] / \partial \boldsymbol{\ell} \cdot \mathrm{w}\right]-\partial\left[\mathrm{c}_{\mathrm{c}}\left(\mathrm{x}, \boldsymbol{\ell}_{\mathrm{k}}\right)\right] / \partial \boldsymbol{\ell}$

A shorter course of study will decrease the probability of passing the exam and hence the benefit from entering the pathway. However, it seems reasonable to assume that ability and training are substitutes, so the marginal benefit of program length is decreasing in ability $\left(\partial^{2} \mathrm{p}_{\mathrm{p}} / \partial \boldsymbol{l} \partial \mathrm{x} \leq 0\right)$, i.e. "smarter" students lose less from a longer course of study than do less able students. Further, given the assumption that the marginal cost of completion is non-decreasing in ability, the impact of a reduction in pathway length will be greater for high-ability students than for low-ability students. This is illustrated in Figure 1, where the subscript 1 denotes a program of length $\boldsymbol{\ell}_{1}$, where $\boldsymbol{\ell}_{1}<\boldsymbol{\ell}_{0}$. Whether the ability of the highest ability and lowest-ability entrants increases or decreases depends on the effects of program length on opportunity costs and the degree to which the decrease in program length affects the likelihood of passing the exam. In Figure 1 I have illustrate a case where the reduction in costs dominates for both high and low ability students. As a result, the shorter pathway attracts higher ability students at each end of the quality spectrum, though the increase is greater at the upper end of ability. Given the assumed uniform distribution of ability, average ability of students entering the shorter pathway is higher than for the longer pathway. Of course, if the training is particularly productive, $\mathrm{B}_{1}$ would be far below Bo and both the maximum and average ability of students entering the shorter pathway could be lower. Thus the effects of program length on the quality of entrants are ambiguous apriori. 


\section{Pathways to Teaching in Florida}

Currently there exist nine different sets of certification requirements or pathways, any one of which can be met in order to obtain a professional teaching certificate in Florida: ${ }^{4}$

- Initial Degree College Courses in Traditional Teacher Preparation Program

- After Degree - District Alternative Certification Competency-based Program

- After Degree - Education Preparation Institute Competency-based Program

- After Degree - A valid ABCTE Passport Certificate in the Subject Area

- After Degree - Two semesters of successful college full-time teaching experience

- Initial and After Degree Approved College Professional Training Option - Content Major \& College Education Courses per Rule 6A-4.006

- After Degree - Professional Preparation College Courses per Rule 6A-4.006

- After Degree - Full Reciprocity

- After Degree - A valid NBPTS Certificate in the Subject Area

The traditional teacher preparation program option requires completion of an approved teacher preparation program at a post-secondary institution within Florida. Program completers must also pass general knowledge and professional education certification tests as well as any necessary subject certification exams.

At present, the most frequently traveled alternative pathway to certification in Florida is the district alternative certification option. Unlike Teach for America or the Teaching Fellows program in New York City, the district alternative certification option does not involve any special recruitment procedures and teachers are not required to work toward an education degree while teaching. In fact, no formal education coursework is required. To become certified under this option, one must pass the standard general knowledge and professional education certification exams and complete a competency-

\footnotetext{
${ }^{4}$ Professional certificates are valid for five years and are renewable. Individuals who have not met all of the requirements for professional certification may receive a temporary certificate that is valid for three years and is non-renewable. The criteria for certification are specified in 48 Florida Statutes 1012.56 (2012). The initial statute authorizing alternative routes became effective July 1, 2002 (see Florida Statutes 1012.56 (2002)).
} 
based alternative certification program. The details of the program vary somewhat across districts, but involve an initial assessment of skills, an individualized training plan, mentoring, a training curriculum that targets a set of "accomplished teacher practices" and summative assessment that documents mastery of the practices. The training programs are frequently web-based, but some also involve collaborations with local community colleges or universities.

Three additional alternative routes to certification, the "Educator Preparation Institute" option, "ABCTE Passport" option and the "College Teaching Experience" option, are all relatively new. ${ }^{5}$ The education preparation institutes (EPIs) are essentially two-semester non-degree programs, nearly all of which are housed in community colleges. Typically they consist of seven required classes and a field experience component. Courses are specific to the EPI program and credits are not transferable to traditional education majors. Coursework is often a combination of face-to-face meetings and online instruction. Individuals completing the EPI program must also pass the standard certification exams to receive professional certification. The $\mathrm{ABCTE}$ passport option requires individuals to obtain a certificate issued by the American Board for Certification of Teacher Excellence and demonstrate professional education competence in the classroom. To obtain the ABCTE certificate candidates must pass both a professional teaching knowledge exam and a subject area exam administered by ABCTE. Candidates prepare for the exams with online and electronic documents provided by ABCTE. As they name implies, the college teaching experience option requires that one have successfully taught for two semesters at a community college or four-year university. No general knowledge or professional education exams are required; applicants need only pass a subject area certification exam.

5. Provisions for the ABCTE option became effective June 10, 2004 (see Florida Statutes 1012.56 (2004). In 2004 Florida Statutes 1004.85 provided the opportunity for postsecondary institutions to create Educator Preparation Institutes. The first EPI programs were approved by the Florida Department of Education in August 2005. 
The "Approved College Professional Training" and "Professional Preparation College Courses" options are essentially indistinguishable. In both cases an individual must complete a handful of core education courses, obtain teaching experience and pass the teacher certification exams. The former option covers cases where an individual receives a non-education college degree but minors in education and takes the required core classes as part of a minor in education. This education-minor route is very new. The later option covers any individual who has successfully completed the required core education courses. The courses need not be part of a formal course of study nor from a single institution. Thus this route is a "catch all" category that includes individuals with a variety of educational backgrounds. Education majors who do not complete all of their institution's teacher preparation program requirements, but have passed the required core education courses can obtain certification through this route. Likewise, individuals who earn a non-education college degree and either took the required education courses while an undergraduate, or completed the required courses once they start teaching, can obtain certification in this manner. In the analysis these two routes are combined under the rubric "Course Analysis."

Due to population growth and constitutionally mandated class-size restrictions, there was a high demand for new teachers in Florida until the economic downturn in Fall 2008. As a result, unlike New York and other states in the Northeast and Midwest, Florida has been a net importer of teachers until recently. There are three avenues by which individuals from out of state can obtain certification when they move to Florida. New graduates of teacher preparation programs outside of Florida must meet the same requirements as those completing traditional teacher preparation programs within Florida. Experienced teachers receive certification in Florida if they possess a valid standard teaching certificate issued by another state or if they hold a valid certificate from the National Board for Professional Teaching Standards (NBPTS). To obtain NBPTS certification a teacher must be certified to teach in 
their state, have three years of experience, submit a portfolio of materials for evaluation and pass an exam. Since NBTS requires pre-existing state certification, the NBPTS option is only relevant for teachers whose state-issued certificate has lapsed or who require certification in a subject area not covered by their state certification. The few teachers who achieve professional certification in this way have been lumped together with certified teachers from states other than Florida in the analysis.

Given the specifics of the certification provisions, the initial analysis of pathways to certification in Florida considers the following categories:

\begin{tabular}{|c|c|}
\hline Pathway & Certification Requirement Options \\
\hline $\begin{array}{l}\text { Graduate of a Florida } \\
\text { Teacher Preparation Program }\end{array}$ & Initial Degree College Courses in Traditional Teacher Preparation Program \\
\hline $\begin{array}{l}\text { District Alternative } \\
\text { Certification Program }\end{array}$ & After Degree - District Alternative Certification Competency-based Program \\
\hline Course Analysis & $\begin{array}{l}\text { Initial and After Degree Approved College Professional Training Option - } \\
\text { Content Major \& College Education Courses per Rule 6A-4.006 } \\
\text { After Degree - Professional Preparation College Courses per Rule 6A-4.006 }\end{array}$ \\
\hline $\begin{array}{l}\text { Graduate of an Out-of-State } \\
\text { Teacher Preparation Program }\end{array}$ & Initial Degree College Courses in Traditional Teacher Preparation Program \\
\hline Certified in Another State & $\begin{array}{l}\text { After Degree - Full Reciprocity } \\
\text { After Degree - A valid NBPTS Certificate in the Subject Area }\end{array}$ \\
\hline ABCTE & After Degree - A valid ABCTE Passport Certificate in the Subject Area \\
\hline $\begin{array}{l}\text { Education Preparation } \\
\text { Institute }\end{array}$ & After Degree - Education Preparation Institute Competency-based Program \\
\hline College Teaching Experience & After Degree - Two semesters of successful college full-time teaching experience \\
\hline
\end{tabular}

However, the descriptive analysis demonstrates that graduates from traditional preparation programs, be they recent in-state or out-of-state graduates, or out-of-state state experienced teachers, possess similar characteristics. Likewise, individuals entering through the catch-all category of "course analysis" are similar to teacher preparation program graduates. I therefore focus on the three distinctly different 
alternative routes, district alternative certification, education preparation institutes and $\mathrm{ABCTE}$, in the subsequent analysis of teacher productivity.

\section{Data}

Data for the analysis come from two sources. The Florida Education Data Warehouse (FLEDW) provides longitudinal information on all public school students, including demographic information, enrollment and attendance, program participation, disciplinary actions and achievement test scores, beginning in 1995. The state administers reading and math tests, known as the "Sunshine State Standards" Florida Comprehensive Achievement Test (FCAT-SSS) to all $3^{\text {rd }}$ through $10^{\text {th }}$ graders in Florida. The FCAT-SSS is a criterion-based exam designed to test for the skills that students are expected to master at each grade level. It is a "high-stakes" test used to determine school grades, student retention in some grades and passage of the $10^{\text {th }}$ grade exam is a requirement for graduation from high school. ${ }^{6}$ The FCAT-SSS was first administered in consecutive grades during the 2000/01 school year and results are currently available through 2009/10.

The FL-EDW data also contain administrative data on individual teachers, including demographic information, experience, educational attainment and certification status. Each classroom has a unique identifier, so I can reliably link teachers and students to specific classrooms at each grade level.

\footnotetext{
${ }^{6}$ Beginning in 1999/00, a second test, the FCAT Norm-Referenced Test (FCAT-NRT) was given in all grades 3-10. The FCAT-NRT was a version of the Stanford Achievement Test used throughout the country and thus provided a national benchmark. No accountability measures were tied to student performance on the FCAT-NRT, which was last administered in Spring 2008. Since the FCAT-SSS exam covers recent years in which many alternatively certified teachers began teaching, we utilize it in the primary analysis of teacher productivity presented in the paper. However, results using the FCAT-NRT are very similar and are available upon request.
} 
The determination of pathways into teaching and teacher certification exam scores is accomplished by linking data files from the Florida Department of Education's Office of Teacher Certification with the FL-EDW data. Pathways are determined from information indicating the method by which each individual teacher was certified.

The ability to link teachers to their university coursework is an additional strength of the Florida data. For relatively young teachers (those who attended a Florida public university or community college since 1995) the FL-EDW data contain complete college transcript information, including entrance exam scores, courses taken, majors and degrees received. Because Florida has a uniform course numbering system, I am able to determine the subject area of each course taken. Certification records allow identification of the undergraduate institution of new teachers, whether they graduated from a public or private university in Florida or elsewhere. However, information on college major and college coursework is only available for teachers who attended public community colleges and universities in Florida. ${ }^{7}$

In order to align the analysis with previous work in New York City and to avoid possible biases, I restrict the sample in two ways. First, students who skip a grade or who repeat a grade are dropped. Second, in order to identify the teacher responsible for instruction, I restrict the analysis to students who receive instruction in the relevant subject area from a single teacher.

\section{Methods}

In order to gauge the impact of pathways into teaching on subsequent teacher performance I estimate a "value-added" model that relates current student achievement to a vector of student/family

\footnotetext{
${ }^{7}$ If students transfer from out of state or between public and private post-secondary institutions in Florida the FL-EDW data will not capture their entire undergraduate record. Therefore coursework information is only used for teachers when at least 100 credit hours are accounted for.
} 
inputs, $\mathbf{X}_{\mathrm{it}}$ (where students are indexed by i), a vector of classroom peer characteristics, $\mathbf{P}_{\text {-ijmt }}$ (where the subscript $-\mathrm{i}$ denotes students other than individual $\mathrm{i}$ in classroom $\mathrm{j}$ in school $\mathrm{m}$ ), a vector of time-varying teacher characteristics, $\mathbf{T}_{\mathrm{kt}}$ (where $\mathrm{k}$ indexes teachers), a vector of time-invariant teacher characteristics $\left(\mathbf{Z}_{\mathrm{k}}\right)$ and time-invariant school characteristics denoted by the "school fixed effect," $\phi_{\mathrm{m}}$ (where $\mathrm{m}$ indexes schools). Student achievement in the prior year, $A_{i t-1}$, serves as a sufficient statistic for all prior schooling inputs. The model can thus be expressed as:

$$
A_{i t}=\beta_{0}+\beta_{1} A_{i t-1}+\boldsymbol{\beta}_{2} \mathbf{X}_{i t}+\boldsymbol{\beta}_{3} \mathbf{P}_{-i j m t}+\boldsymbol{\beta}_{4} \mathbf{T}_{k t}+\boldsymbol{\beta}_{5} \mathbf{Z}_{k}+\phi_{m}+v_{i t}
$$

where $v_{\text {it }}$ is a normally distributed, mean zero error. The effects of teacher preparation pathways are captured by a set of indicator variables contained in the vector $\mathbf{Z}_{\mathrm{k}}$. As discussed in Mihaly, et al. (2011), the inclusion of school fixed effects in achievement models designed to evaluate teacher pre-service programs can be problematic because identification requires that a school have early-career teachers from multiple programs. Even if the minimum requirements for identification are met, biases can still result if the schools with teachers from multiple programs are atypical or the teachers from different programs who teach in the same school are not representative of the average teacher from their program. Due to the problems associated with simultaneously identifying pathway and school effects, both models with and without school effects are estimated.

The basic model we use to estimate student achievement, in which student heterogeneity is accounted for by observable student characteristics and the impact of prior educational inputs is allowed to decay over time (i.e. $\beta_{1}$ can be less than one), is just one of many possible specifications. However, recent experimental and simulation-based evidence suggests this model is likely to produce relatively unbiased estimates of teacher effects under a range of conditions (Kane and Staiger (2008), Guarino, Reckase and Wooldridge (2012)). Further, the use of student fixed effects to account for student 
heterogeneity is problematic in our case because identification requires that a student is taught by teachers from different pathways; the large proportion of students who only encounter traditionally prepared teachers would add nothing to the identification of pathway effects. ${ }^{8}$

\section{Results}

\section{A. Summary Statistics}

Table 1 reports mean characteristics of teachers who obtained certification by graduating from a Florida teacher preparation program versus those who entered from each of the other seven routes. Teachers who obtain certification through the three distinctly alternative routes (district alternative certification, Educator Preparation Institutes and ABCTE) tend to be older and are more likely to be male and to be white than traditionally prepared teachers. The teachers from the distinctly alternative routes also have stronger credentials than graduates of Florida teacher preparation programs. A greater proportion graduated from the most competitive colleges. Similarly, teachers entering via the district alternative certification and EPI pathways were more likely to pass the general knowledge certification exams on the first try. Virtually all ABCTE teachers passed each of the certification exams on the first try. The variation in certification exam performance appears to be due in part to differences in precollege ability; combined SAT scores are significantly higher for alternatively certified teachers, about 70 points greater for district alternative certification and EPI teachers and over 140 points greater for ABCTE teachers.

\footnotetext{
${ }^{8}$ Though not reported here, I also estimated pathway effects from an achievement model with complete persistence $\left(\beta_{1}=1\right.$, which makes the dependent variable the achievement gain, $\left.\Delta \mathrm{A}_{\mathrm{it}}\right)$. Results from this "gain-score" specification were qualitatively similar and are available upon request. See Harris, Sass, and Semykina (2011) for a detailed discussion of value-added models.
} 
If alternatively certified teachers are entering teaching as a second career (as suggested by their more advanced age), they might be more likely to teach in middle and high school. This could skew the comparisons, since the majority of traditionally prepared teachers teach at the elementary school level. However, when comparing the characteristics of traditionally-prepared and alternatively certified teachers who are certified in elementary education in Table 2, the same general pattern of differences remains. While the differences are slightly smaller, results are similar to those from the full sample.

Data on the modal college majors of teachers, broken down by pathway and certification subject area are provided in Table 3. Teachers who entered via the catch-all "Course Analysis" pathway were most often elementary education majors, who evidently just submitted proof of their college coursework rather than completion of their University's preparation program to satisfy initial certification requirements. In contrast, teachers who entered from the distinctly "alternative" routes of district alternative certification, EPIs or ABCTE, possessed bachelor's degrees in a very different set of majors. For the district alternative certification and ABCTE pathways the modal college major is English Language and Literature, while for EPI it is Psychology. ${ }^{9}$ Similarly, for elementary education and middle school math certifications, the most common route for traditionally prepared teachers is elementary teacher education, whereas for the alternate routes Business Administration and Psychology dominate. At the high school level, traditionally prepared teachers tend to earn degrees in the relevant sub-discipline of education (e.g. mathematics teacher education) while teachers from the district alternative certification and $\mathrm{ABCTE}$ pathways are most likely to hold degrees in the relevant subject area (e.g. math or biology). In contrast teachers who entered via the EPI route tend not to have baccalaureate degrees in a closely related field.

\footnotetext{
${ }^{9}$ Major information is only available for degree recipients of Florida public universities. Thus college major is known for only about half of the teachers who obtained certification through pathways other than completing a Florida teacher preparation program.
} 
Information on the specific coursework of Florida teacher preparation program graduates relative to that of entrants from the three distinctively alternative routes is provided in Table 4. Florida teacher preparation program graduates earn over half their credits in education courses, whereas alternate-route teachers average one three credit-hour education course or less. ${ }^{10}$ Interestingly, both traditionally prepared and alternatively-certified teachers average about two math or statistics courses. Course taking differences in the sciences are more pronounced. Whereas traditionally prepared teachers average just under three sciences courses (8.54 credit hours), district alternative certification and EPI completers take nearly five science courses on average. The few number of ABCTE teachers with complete college transcripts average about 10 science courses (30.92 credit hours).

\section{B. Value-Added Model Estimates}

Estimates from equation (1) are presented in Table 5. Estimates of the value added of districtalternative-certification, EPI and ABCTE teachers for both math and reading achievement are displayed. ${ }^{11}$ Test scores are normed by grade and year so coefficient estimates can be interpreted in standard deviation units of student achievement. In order to minimize the influence of differential onthe-job training, such as learning from peer teachers, the sample is limited to teachers in their first three years of teaching in Florida. ${ }^{12}$

\footnotetext{
${ }^{10}$ The "Education Coursework" category only includes traditional education courses; courses included in EPI programs are not counted.

${ }^{11}$ The reading sample sizes are smaller than those for math due to the restriction that students must be taught by a single teacher in a single course in the relevant subject. The prevalence of multiple teachers and courses is much greater in language arts that in math. For example, in 2009, the average number of distinct math courses per student was 1.13 whereas for language arts it was 1.35. Correspondingly, the average number of math teachers was 1.14 and the number of language arts teachers was 1.75 .

12 The value-added analysis includes teachers with 0-2 years of experience, whereas the descriptive statistics of teachers by pathway are only for teachers in their first year of teaching. Consequently the samples are different.
} 
In math, the differences in teacher productivity are all highly significant and quantitatively substantial. ABCTE-route teachers, who face no course requirements and need to make virtually no specific investments to become a teacher, outperform traditionally prepared teachers by six to eight percent of a standard deviation in student achievement. This is about two to three times the difference in productivity between a rookie teacher and one with three to five years of experience. Given the standard deviation in math teacher value added in Florida is about 0.38 , this is equivalent to 17 to 21 percent of a standard deviation in teacher effectiveness. Based on the recent estimates of the long-run impacts of teacher quality by Chetty, Friedman and Rockoff (2011), this implies an earnings differential of about 0.2 percent at age 28 or roughly a $\$ 1,000$ increase in the present value of lifetime income at age 12 . Given an average (math) class size of 23.7, the per-class differential in present value terms is nearly $\$ 24,000$. District-alternative-certification-route teachers, who face somewhat greater requirements to enter teaching than do ABCTE-route teachers, exhibit a smaller productivity edge over traditionally prepared math teachers, equal to 1.0-2.5 percent of a standard deviation in student achievement. EPIroute teachers, who face greatest coursework requirements and must incur the highest occupationspecific investment to become a teacher, are substantially less productive than other alternative-route teachers. Their value added lags behind that of traditionally prepared teachers by two to four percent of a standard deviation in student achievement.

Consistent with prior studies, the observed differences in teacher value-added across pathways are less pronounced in reading than in math. As with math, ABCTE-route and district-alternativecertification-route teachers outperform traditionally prepared teachers, though the magnitude of the difference is much smaller, roughly 1.5-2.0 percent of a standard deviation in student achievement. EPIroute teachers lag behind traditionally prepared teachers; their value added is two to three percentage points lower. 
Table 6 presents results from the same achievement model as were presented in Table 5, but for the more homogeneous sample of middle and high school teachers. The results are quite similar to the full-sample results in Table 5. As with the full sample, ABCTE teachers exhibit significantly higher value added, particularly in math. District-alternative-certification teachers also outperform their traditionally prepared peers, but by a smaller margin. EPI teachers lag behind traditionally prepared teachers in both math and reading and their value added trails that of ABCTE teachers by as much as 0.1 standard deviations in student math achievement.

As noted above, changes in licensing requirements can have important impacts on the tails of the teacher quality distribution, even if average quality is unaffected. To gauge the effects of licensure requirements on the quality range of teachers I present kernel density plots of the distribution of teacher effect estimates broken down by pathway in Figure 2 (for math) and Figure 3 (for reading). Like the pathway effects, the teacher effects represent impacts on normalized student test scores and thus are measured in standard deviation units. The teacher effect estimates are obtained by estimating equation (3), replacing the pathway indicators with individual teacher fixed effects. While it is difficult to make definitive judgments about the differences in the distributions of teacher quality, the teacher effect distribution for the ABCTE pathway, which exhibited the greatest average difference in teacher quality from the traditional pathway, appears to have a shorter left tail and a somewhat smaller proportion of below-average quality teachers. It also appears that the Educator Preparation Institute pathway, which has the greatest course requirements of the three major alternative pathways, is essentially a leftward shirt of the tradition pathway distribution, with fewer teachers at the extremes. The distribution of teacher quality from the district alternative certification pathway exhibits the smallest deviation from the quality distribution of teachers from the traditional pathway; the variance is smaller with the range of teacher effects being less than that from the distribution of traditionally prepared teachers. 


\section{VIII.Summary and Conclusions}

Traditionally, the only way to be licensed to teach was to major in education and complete a university-based teacher preparation program. In recent years there has been a shift away from this paradigm as many states have adopted laws and regulations permitting individuals to enter the teaching profession in other ways. Much attention has been paid to the peace-corps style program called Teach for America, which recruits graduates from prestigious universities to work in urban schools for a minimum of two years. Indeed Teach for America has received the most examination of any alternative certification program. However, TFA teachers only make up a small minority of alternatively prepared teachers in most states. In this paper I explore the effects of more generic alternative certification programs that have no special recruitment efforts, no minimum time commitment and do not require participants to take formal university based education courses while teaching.

Using a rich panel data set from Florida I explore the characteristics of individuals who enter teaching through alternative certification programs and measure their effectiveness in promoting student achievement. Florida has three distinct alternative certification programs. The largest is the "District Alternative Certification" program which allows applicants to become certified through an individualized training program that includes mentoring and on-line training, but does not require any formal education coursework. Smaller, but growing in popularity are the Educator Preparation Institutes, which involve taking two semesters of non-transferrable coursework at a community college, and the ABCTE pathway, which has no coursework requirement whatsoever; all that is required is passage of a test.

In general I find that alternatively certified teachers have stronger pre-service academic skills, as evidenced by higher initial pass rates on certification exams and higher college entrance exam scores than traditionally prepared teachers. The measured contribution of alternatively certified teachers varies 
considerably across pathways, however. The value added of district-alternative certification teachers is generally one to two percent of a standard deviation higher than that of recent Florida teacher preparation program graduates. In contrast, the value-added scores of EPI completers are two to four percent of a standard deviation below those of traditionally prepared teachers. Most stark are the differences in the performance of ABCTE teachers relative to traditionally prepared teachers in math. ABCTE teachers outperform their traditionally prepared colleagues by a wide margin - six to eight percent of a standard deviation in student achievement.

The positive results for ABCTE math teachers must be interpreted with caution, given the modest sample of ABCTE teachers in tested grades. However, when combined with prior evidence on TFA teachers in other locales, some important trends emerge. For both TFA and ABCTE no prior coursework in education is required, but in both cases perspective teachers come from more competitive schools and have better pre-college test scores. It appears that the low entry requirements of both programs attract individuals with greater intellectual ability and (at least for math) this trumps any human capital enhancement that may accrue from coursework in education. In contrast, the EPI pathway, which requires essentially two semesters of non-transferable coursework attracts individuals with somewhat weaker measured ability and they end up performing worse, on average, than traditionally prepared teachers in math.

The varied findings for the three programs in Florida highlight the fact that alternative certification programs are in fact quite diverse and one should be cautious about making blanket statement about the relative performance of "alternatively certified" teachers. However, it does appear that certification programs with low entry requirements can produce teachers that are as productive, or even more productive, than traditionally prepared teachers. Given the opportunity cost of a four-year 
degree in education, this implies that allowing some low-cost portals into the teaching profession would appear to be an efficient mechanism for increasing the supply of teachers. 


\section{References}

Aaronson, Daniel, Lisa Barrow and William Sander (2007). "Teachers and Student Achievement in the Chicago Public High Schools.” Journal of Labor Economics 25(1): 95-135.

Akerlof, George A. (1970). “The Market for 'Lemons': Quality Uncertainty and the Market Mechanism.” Quarterly Journal of Economics 84(3):488-500.

Angrist, Joshua, and Jonathan Guryan (2008). "Does Teacher Testing Raise Teacher Quality? Evidence From State Certification Requirements.” Economics of Education Review 27(5):483-503.

Berger, Mark C. and Eugenia F. Toma (1994). "Variation in state education policies and effects on student performance." Journal of Policy Analysis and Management, 13, 477-491.

Boyd, Donald, Pamela Grossman, Hamilton Lankford, Susanna Loeb and James Wyckoff (2006). "How Changes in Entry Requirements Alter the Teacher Workforce and Affect Student Achievement." Education Finance and Policy 1(2):176-216.

Carroll, Sidney L. and Robert J. Gaston (1981). "Occupational restrictions and the quality of service received: Some evidence.” Southern Economic Journal 47(4):959-976.

Chetty, Raj, John N. Friedman and Jonah Rockoff (2011). "The Long-Term Impacts of Teachers: Teacher Value-Added and Student Outcomes in Adulthood." Cambridge, MA: National Bureau of Economic Research, Working Paper No. 17699.

Constantine, Jill, Daniel Player, Tim Silva, Kristin Hallgren, Mary Grider and John Deke (2009). "An Evaluation of Teachers Trained through Different Routes to Certification." Washington, DC: U.S. Department of Education, NCEE 2009-4043.

Currie, Janet and V. Joseph Hotz (2004). “Accidents will Happen?: Unintentional Childhood Injuries and the Effects of Child Care Regulations.” Journal of Health Economics 23(1):25-59.

Garet, Michael S., Stephanie Cronen, Marian Eaton, Anja Kurki, Meredith Ludwig, Wehmah Jones, Kazuaki Uekawa, Audrey Falk, Howard S. Bloom, Fred Doolittle, Pei Zhu, and Laura Sztejnberg (2008). "The Impact of Two Professional Development Interventions on Early Reading Instruction and Achievement." Washington, DC: U.S. Department of Education, NCEE 20084031.

Garet, Michael S., Andrew J. Wayne, Fran Stancavage, James Taylor, Marian Eaton, Kirk Walters, Mengli Song, Seth Brown, Steven Hurlburt, Pei Zhu, Susan Sepanik and Fred Doolittle (2010). "Middle School Mathematics Professional Development Impact Study: Findings After the First Year of Implementation.” Washington, DC: U.S. Department of Education, NCEE 2010-4009.

Gaumer, Gary L. 1984. "Regulating Health Professionals: A Review of the Empirical Literature." The Milbank Memorial Fund Quarterly. Health and Society” 62(3):380-416. 
Glazerman, Steven, Daniel Mayer and Paul Decker (2006). “Alternative Routes to Teaching: The Impacts of Teach for America on Student Achievement and Other Outcomes." Journal of Policy Analysis and Management 25(1):75-96.

Glazerman, Steven and Allison Seifullah (2012). "An Evaluation of the Chicago Teacher Advancement Program (Chicago TAP) After Four Years.” Washington, DC: Mathematica Policy Resarch.

Guarino, Cassandra, Mark Reckase, and Jeffrey Wooldridge. 2012. "Can Value-Added Measures of Teacher Education Performance be Trusted." Working Paper \#18. The Education Policy Center at Michigan State University. Accessible online at http://education.msu.edu/epc/publications/ documents/WP18Guarino-Reckase-Wooldridge-2012-Can-Value-Added-Measures-of-TeacherPerformance-Be-T_000.pdf

Harris, Douglas N. and Tim R. Sass (2011). "Teacher Training, Teacher Quality and Student Achievement." Journal of Public Economics 95: 798-812.

Harris, Douglas N., Tim R. Sass and Anastasia Semykina (2011). "Value-Added Models and the Measurement of Teacher Productivity." Washington DC: National Center for Analysis of Longitudinal Data in Education Research, Working Paper No. 54.

Jacob, Brian A. and Lars Lefgren. 2004. "The Impact of Teacher Training on Student Achievement: Quasi-Experimental Evidence from School Reform Efforts in Chicago," Journal of Human Resources 39(1):50-79.

Johnson, Linda L. and Christine Loucks. 1986. "The Effect of State Licensing Regulations on the Real Estate Brokerage Industry," AREUEA Journal 14(4):567-582.

Kane, Thomas J., Jonah E. Rockoff and Douglas O. Staiger. 2008. "What Does Certification Tell Us About Teacher Effectiveness? Evidence from New York City." Economics of Education Review 27(6):615-631.

Kane, Thomas J. and Douglas O. Staiger. 2008. Estimating Teacher Impacts on Student Achievement: An Experimental Evaluation.” Working Paper \#14607. Cambridge, MA: National Bureau of Economic Research.

Kleiner, Morris M. 2000. “Occupational Licensing,” Journal of Economic Perspectives 14(4):189-202.

Kleiner, Morris M., and Alan B. Krueger. 2010. "The Prevalence and Effects of Occupational Licensing." British Journal of Industrial Relations 48(4): 676-87.

Kleiner, Morris M. and Robert T. Kudrle (2000). "Does Regulation Affect Economic Outcomes? The Case of Dentistry." Journal of Law and Economics, 43:547-582.

Larsen, Bradley. 2013. “Occupational Licensing and Quality: Distributional and Heterogeneous Effects in the Teaching Profession." Unpublished manuscript.

Leland, Hayne E. 1979. "Quacks, Lemons and the Market Mechanism: A Theory of Minimum Quality Standards." Journal of Political Economy 87:1328-46. 
Lott, John R., Jr. 1996. "Why Does Professional Licensing Rely on Minimum Schooling Requirements." Working paper, University of Chicago.

Maurizi, Alex (1980). "The impact of regulation on quality: The case of California contractors." In Occupational Licensure and Regulation (S. Rottenberg, ed.). Washington, D.C.: American Enterprise Institute for Public Policy Research, 299-333.

Peltzman, Sam. 1976. "Toward a More General Theory of Regulation." Journal of Law and Economics 19:211-40.

Ramseyer, J. Mark and Eric B. Rasmussen. 2012. "Improving the Bar by Lowering the Bar: Licensing Difficulty and Attorney Quality in Japan.” Unpbublished manuscript.

Rivkin, Steven G., Eric A. Hanushek and John F. Kain 2005. "Teachers, Schools and Academic Achievement." Econometrica 73(2): 417-58.

Shapiro, Carl. 1986. "Investment, Moral Hazard and Occupational Licensing." Review of Economic Studies 53(5): 843-62.

Springer, Matthew G., Dale Ballou, Laura Hamilton, Vi-Nhuan Le, J.R. Lockwood, Daniel F. McCaffrey, Matthew Pepper and Brian M. Stecher (2010). Teacher Pay for Performance: Experimental Evidence from the Project on Incentives in Teaching. Nashville, TN: National Center on Performance Incentives.

Springer, Matthew G., John F. Pane, Vi-Nhuan Le, Daniel F. McCaffrey, Susan Freeman Burns, Laura S. Hamilton and Brian Stecher (2012). Team Pay for Performance: Experimental Evidence from the Round Rock Pilot Project on Team Incentives. Educational Evaluation and Policy Analysis. 34(4), 367-390.

Stephenson, E. Frank and Erin E. Wendt. 2009. "Occupational Licensing: Scant Treatment in Labor Texts," Econ Journal Watch 6(2):181-194.

Stigler, George J. 1971. "The Theory of Economic Regulation." Bell Journal of Economics and Management Science 2:3-21.

Wilson, Suzanne, Robert E. Floden and Joan Ferrini-Mundy. 2001. Teacher Preparation Research: Current Knowledge, Gaps, and Recommendations. Seattle, WA: Center for the Study of Teaching and Policy.

$\mathrm{Xu}$, Zeyu, Jane Hannaway and Colin Taylor. 2011. "Making a Difference? The Effects of Teach for America in High School." Journal of Policy Analysis and Management 30(3):447-469. 
Table 1 - Select Characteristics of First-Year Teachers by Pathway (Teachers with any Certification)

\begin{tabular}{|c|c|c|c|c|c|c|c|c|}
\hline Pathway & $\begin{array}{l}\text { Proportion } \\
\text { from Most } \\
\text { Competitive } \\
\text { Colleges } \\
\text { (Barron's } \\
\text { Ratings) } \\
\end{array}$ & $\begin{array}{l}\text { Proportion } \\
\text { from Least } \\
\text { Competitive } \\
\text { Colleges } \\
\text { (Barron's } \\
\text { Ratings) } \\
\end{array}$ & $\begin{array}{l}\text { Proport } \\
\text { Passed } \\
\text { Knowle } \\
\text { Certific } \\
\text { Exam o } \\
\text { Attemp }\end{array}$ & $\begin{array}{l}\text { nho } \\
\text { eneral } \\
\text { ge State } \\
\text { ion } \\
\text { First }\end{array}$ & $\begin{array}{l}\text { Pro- } \\
\text { portion } \\
\text { Non- } \\
\text { White } \\
\end{array}$ & $\begin{array}{l}\text { Pro- } \\
\text { portion } \\
\text { Male } \\
\end{array}$ & $\begin{array}{l}\text { Median } \\
\text { Age }\end{array}$ & $\begin{array}{l}\text { Average } \\
\text { Total } \\
\text { SAT } \\
\text { Score } \\
\end{array}$ \\
\hline $\begin{array}{l}\text { Graduate of a Florida } \\
\text { Teacher Preparation } \\
\text { Program } \\
(n=27,503)\end{array}$ & 0.142 & 0.182 & $\begin{array}{l}\text { Math } \\
\text { Reading } \\
\text { English } \\
\text { Essay }\end{array}$ & $\begin{array}{l}0.691 \\
0.818 \\
0.836 \\
0.914\end{array}$ & 0.308 & 0.130 & 25.0 & 940 \\
\hline $\begin{array}{l}\text { Course Analysis } \\
(n=39,525)\end{array}$ & $0.195^{*}$ & $0.157^{*}$ & $\begin{array}{l}\text { Math } \\
\text { Reading } \\
\text { English } \\
\text { Essay }\end{array}$ & $\begin{array}{l}0.650^{*} \\
0.824 \\
0.828 \\
0.879^{*}\end{array}$ & $0.327^{*}$ & $0.232 *$ & $29.0 *$ & $958^{*}$ \\
\hline $\begin{array}{l}\text { Certified in Another } \\
\text { State } \\
(\mathrm{n}=18,991)\end{array}$ & $0.077 *$ & $0.211 *$ & $\begin{array}{l}\text { Math } \\
\text { Reading } \\
\text { English } \\
\text { Essay }\end{array}$ & $\begin{array}{l}0.599^{*} \\
0.814 \\
0.815 \\
0.866^{*}\end{array}$ & $0.167^{*}$ & $0.190 *$ & $32.0 *$ & $994 *$ \\
\hline $\begin{array}{l}\text { Graduate of an Out- } \\
\text { of-State Teacher } \\
\text { Preparation Program } \\
(n=8,627)\end{array}$ & $0.072 *$ & $0.229^{*}$ & $\begin{array}{l}\text { Math } \\
\text { Reading } \\
\text { English } \\
\text { Essay }\end{array}$ & $\begin{array}{l}0.586^{*} \\
0.722^{*} \\
0.743^{*} \\
0.725^{*}\end{array}$ & $0.277^{*}$ & $0.225^{*}$ & $33.0 *$ & $894 *$ \\
\hline $\begin{array}{l}\text { District Alternative } \\
\text { Certification Program } \\
(\mathrm{n}=3,615)\end{array}$ & $0.231^{*}$ & $0.121 *$ & $\begin{array}{l}\text { Math } \\
\text { Reading } \\
\text { English } \\
\text { Essay }\end{array}$ & $\begin{array}{l}0.769^{*} \\
0.920^{*} \\
0.925^{*} \\
0.923\end{array}$ & $0.269^{*}$ & $0.316^{*}$ & $31.0 *$ & $1015^{*}$ \\
\hline $\begin{array}{l}\text { Educator Preparation } \\
\text { Institute } \\
(\mathrm{n}=772)\end{array}$ & $0.287 *$ & $0.098 *$ & $\begin{array}{l}\text { Math } \\
\text { Reading } \\
\text { English } \\
\text { Essay }\end{array}$ & $\begin{array}{l}0.835^{*} \\
0.917^{*} \\
0.950^{*} \\
0.955^{*}\end{array}$ & $0.214^{*}$ & $0.236^{*}$ & $26.0 *$ & $1006^{*}$ \\
\hline $\begin{array}{l}\text { ABCTE } \\
(n=137)\end{array}$ & $0.236^{*}$ & 0.157 & $\begin{array}{l}\text { Math } \\
\text { Reading } \\
\text { English } \\
\text { Essay }\end{array}$ & $\begin{array}{l}0.947 * \\
1.000^{*} \\
1.000^{*} \\
0.982^{*}\end{array}$ & $0.175^{*}$ & $0.307 *$ & $30.0 *$ & $1081^{*}$ \\
\hline $\begin{array}{l}\text { College Teaching } \\
\text { Experience } \\
(\mathrm{n}=106)\end{array}$ & $0.344^{*}$ & $0.083^{*}$ & $\begin{array}{l}\text { Math } \\
\text { Reading } \\
\text { English } \\
\text { Essay }\end{array}$ & $\begin{array}{l}0.600 \\
0.750 \\
0.650 \\
0.947\end{array}$ & 0.276 & $0.462 *$ & $45.0 *$ & 949 \\
\hline
\end{tabular}

Note: "most competitive" category includes "most competitive," "highly competitive" and "special" designations; "least competitive" category includes "less competitive" and "non-competitive" Barron's designations. The omitted category includes "very competitive" and "competitive" schools. Number of observations based on gender; observations may be less for other variables. Values not reported if relevant data are available for fewer than 10 percent of teachers from the given pathway or if total number of teachers in pathway is less than 25 . $*$ t-test indicates mean significantly different than mean for graduates of Florida teacher preparation programs at 95 percent confidence level. 
Table 2 - Select Characteristics of First-Year Teachers by Pathway (Teachers with Elementary Ed. Certification)

\begin{tabular}{|c|c|c|c|c|c|c|c|c|}
\hline Pathway & $\begin{array}{l}\text { Proportion } \\
\text { from Most } \\
\text { Competitive } \\
\text { Colleges } \\
\text { (Barron's } \\
\text { Ratings) } \\
\end{array}$ & $\begin{array}{l}\text { Proportion } \\
\text { from Least } \\
\text { Competitive } \\
\text { Colleges } \\
\text { (Barron's } \\
\text { Ratings) } \\
\end{array}$ & $\begin{array}{l}\text { Proporti } \\
\text { Passed C } \\
\text { Knowled } \\
\text { Certifica } \\
\text { Exam on } \\
\text { Attempt } \\
\end{array}$ & $\begin{array}{l}\text { on who } \\
\text { eneral } \\
\text { ge State } \\
\text { tion } \\
\text { First } \\
\end{array}$ & $\begin{array}{l}\text { Pro- } \\
\text { portion } \\
\text { Non- } \\
\text { White } \\
\end{array}$ & $\begin{array}{l}\text { Pro- } \\
\text { portion } \\
\text { Male } \\
\end{array}$ & $\begin{array}{l}\text { Median } \\
\text { Age }\end{array}$ & $\begin{array}{l}\text { Average } \\
\text { Total } \\
\text { SAT } \\
\text { Score } \\
\end{array}$ \\
\hline $\begin{array}{l}\text { Graduate of a Florida } \\
\text { Teacher Preparation } \\
\text { Program } \\
(\mathrm{n}=18,991)\end{array}$ & 0.113 & 0.197 & $\begin{array}{l}\text { Math } \\
\text { Reading } \\
\text { English } \\
\text { Essay }\end{array}$ & $\begin{array}{l}0.685 \\
0.815 \\
0.839 \\
0.918\end{array}$ & 0.299 & 0.067 & 25.0 & 928 \\
\hline $\begin{array}{l}\text { Course Analysis } \\
(\mathrm{n}=15,297)\end{array}$ & $0.170^{*}$ & $0.178^{*}$ & $\begin{array}{l}\text { Math } \\
\text { Reading } \\
\text { English } \\
\text { Essay }\end{array}$ & $\begin{array}{l}0.630^{*} \\
0.811 \\
0.812^{*} \\
0.888^{*}\end{array}$ & 0.300 & $0.090^{*}$ & $29.0 *$ & $945^{*}$ \\
\hline $\begin{array}{l}\text { Certified in Another } \\
\text { State } \\
(n=11,208)\end{array}$ & $0.066^{*}$ & $0.217^{*}$ & $\begin{array}{l}\text { Math } \\
\text { Reading } \\
\text { English } \\
\text { Essay }\end{array}$ & $\begin{array}{l}0.603^{*} \\
0.830 \\
0.844 \\
0.916\end{array}$ & $0.158^{*}$ & $0.099 *$ & $30.0^{*}$ & $988^{*}$ \\
\hline $\begin{array}{l}\text { Graduate of an Out- } \\
\text { of-State Teacher } \\
\text { Preparation Program } \\
(n=4,333)\end{array}$ & $0.064 *$ & $0.246^{*}$ & $\begin{array}{l}\text { Math } \\
\text { Reading } \\
\text { English } \\
\text { Essay }\end{array}$ & $\begin{array}{l}0.584^{*} \\
0.755^{*} \\
0.770^{*} \\
0.761^{*}\end{array}$ & $0.244 *$ & $0.101^{*}$ & $32.0 *$ & $891^{*}$ \\
\hline $\begin{array}{l}\text { District Alternative } \\
\text { Certification Program } \\
(\mathrm{n}=636)\end{array}$ & $0.219^{*}$ & $0.119^{*}$ & $\begin{array}{l}\text { Math } \\
\text { Reading } \\
\text { English } \\
\text { Essay }\end{array}$ & $\begin{array}{l}0.789^{*} \\
0.951^{*} \\
0.947 * \\
0.936\end{array}$ & $0.186^{*}$ & $0.127^{*}$ & $32.0^{*}$ & $994 *$ \\
\hline $\begin{array}{l}\text { Educator Preparation } \\
\text { Institute } \\
(\mathrm{n}=330)\end{array}$ & 0.281 & $0.063^{*}$ & $\begin{array}{l}\text { Math } \\
\text { Reading } \\
\text { English } \\
\text { Essay }\end{array}$ & $\begin{array}{l}0.871^{*} \\
0.926^{*} \\
0.949^{*} \\
0.959^{*}\end{array}$ & $0.139 *$ & 0.097 & $27.0^{*}$ & $995^{*}$ \\
\hline $\begin{array}{l}\text { ABCTE } \\
(\mathrm{n}=56)\end{array}$ & $0.255^{*}$ & 0.191 & $\begin{array}{l}\text { Math } \\
\text { Reading } \\
\text { English } \\
\text { Essay }\end{array}$ & $\begin{array}{l}1.000^{*} \\
1.000^{*} \\
1.000^{*} \\
1.000^{*}\end{array}$ & $0.179 *$ & 0.143 & $33.5^{*}$ & $1108^{*}$ \\
\hline $\begin{array}{l}\text { College Teaching } \\
\text { Experience } \\
(\mathrm{n}=26)\end{array}$ & 0.318 & $0.00^{*}$ & $\begin{array}{l}\text { Math } \\
\text { Reading } \\
\text { English } \\
\text { Essay }\end{array}$ & $\begin{array}{l}0.500 \\
0.889 \\
0.667 \\
1.000^{*}\end{array}$ & 0.308 & 0.077 & $39.5^{*}$ & 924 \\
\hline
\end{tabular}

Note: "most competitive" category includes "most competitive," "highly competitive" and "special" designations; "least competitive" category includes "less competitive" and "non-competitive" Barron's designations. The omitted category includes "very competitive" and "competitive" schools. Number of observations based on gender; observations may be less for other variables. Values not reported if relevant data are available for fewer than 10 percent of teachers from the given pathway or if total number of teachers in pathway is less than 20. * t-test (for means) or chi-squared test (for medians) indicates mean significantly different than mean for graduates of Florida teacher preparation programs at 95 percent confidence level. Sample sizes refer number of teachers with demographic information. The numbers of teachers with test scores and college selectivity information is smaller. 
Table 3 - Modal Major of First Bachelor's Degree by Pathway and Certification Area

\begin{tabular}{|c|c|c|c|c|c|}
\hline \multirow[b]{2}{*}{ Pathway } & \multicolumn{5}{|c|}{ Modal Major of First Bachelor's Degree } \\
\hline & All Certifications & $\begin{array}{c}\text { Elementary } \\
\text { Education } \\
\text { Certification } \\
\end{array}$ & $\begin{array}{c}\text { Middle School } \\
\text { Math } \\
\text { Certification } \\
\end{array}$ & $\begin{array}{l}\text { High School } \\
\text { Math } \\
\text { Certification } \\
\end{array}$ & $\begin{array}{l}\text { Biology } \\
\text { Certification }\end{array}$ \\
\hline $\begin{array}{l}\text { Graduate of a } \\
\text { Florida Teacher } \\
\text { Preparation Program }\end{array}$ & $\begin{array}{l}\text { Elementary } \\
\text { Teacher } \\
\text { Education } \\
(\mathrm{n}=17,323)\end{array}$ & $\begin{array}{l}\text { Elementary } \\
\text { Teacher } \\
\text { Education } \\
(12,010)\end{array}$ & $\begin{array}{l}\text { Elementary } \\
\text { Teacher } \\
\text { Education } \\
(\mathrm{n}=315)\end{array}$ & $\begin{array}{l}\text { Mathematics } \\
\text { Teacher } \\
\text { Education } \\
(\mathrm{n}=424)\end{array}$ & $\begin{array}{l}\text { Biology } \\
(n=210)\end{array}$ \\
\hline Course Analysis & $\begin{array}{l}\text { Elementary } \\
\text { Teacher } \\
\text { Education } \\
(\mathrm{n}=11,699)\end{array}$ & $\begin{array}{l}\text { Elementary } \\
\text { Teacher } \\
\text { Education } \\
(\mathrm{n}=4,662)\end{array}$ & $\begin{array}{l}\text { Elementary } \\
\text { Teacher } \\
\text { Education } \\
(\mathrm{n}=422)\end{array}$ & $\begin{array}{l}\text { Mathematics } \\
\text { Teacher } \\
\text { Education } \\
(\mathrm{n}=368)\end{array}$ & $\begin{array}{l}\text { Biology } \\
(n=300)\end{array}$ \\
\hline $\begin{array}{l}\text { Certified in Another } \\
\text { State }\end{array}$ & $\begin{array}{l}\text { Elementary } \\
\text { Teacher } \\
\text { Education } \\
(\mathrm{n}=383)\end{array}$ & $\begin{array}{c}\text { Elementary } \\
\text { Teacher } \\
\text { Education } \\
(\mathrm{n}=212)\end{array}$ & $\begin{array}{l}\text { Elementary } \\
\text { Teacher } \\
\text { Education } \\
(\mathrm{n}=14)\end{array}$ & $\begin{array}{l}\text { Mathematics } \\
\text { Teacher } \\
\text { Education } \\
(\mathrm{n}=13)\end{array}$ & $\begin{array}{l}\text { Biology } \\
(n=11)\end{array}$ \\
\hline $\begin{array}{l}\text { Graduate of an Out- } \\
\text { of-State Teacher } \\
\text { Preparation Program }\end{array}$ & $\begin{array}{l}\text { Elementary } \\
\text { Teacher } \\
\text { Education } \\
(\mathrm{n}=109)\end{array}$ & $\begin{array}{l}\text { Elementary } \\
\text { Teacher } \\
\text { Education } \\
(\mathrm{n}=44)\end{array}$ & & & \\
\hline $\begin{array}{l}\text { District Alternative } \\
\text { Certification } \\
\text { Program }\end{array}$ & $\begin{array}{l}\text { English Lang. } \\
\text { \& Literature } \\
(\mathrm{n}=1,108)\end{array}$ & $\begin{array}{l}\text { Psychology } \\
(\mathrm{n}=185)\end{array}$ & $\begin{array}{c}\text { Business } \\
\text { Administration } \\
(\mathrm{n}=89)\end{array}$ & $\begin{array}{l}\text { Mathematics } \\
\quad(\mathrm{n}=50)\end{array}$ & $\begin{array}{c}\text { Biology } \\
(n=73)\end{array}$ \\
\hline $\begin{array}{l}\text { Educator } \\
\text { Preparation Institute }\end{array}$ & $\begin{array}{l}\text { Psychology } \\
(\mathrm{n}=331)\end{array}$ & $\begin{array}{c}\text { Psychology } \\
(\mathrm{n}=131)\end{array}$ & $\begin{array}{c}\text { Business } \\
\text { Administration } \\
(\mathrm{n}=24)\end{array}$ & $\begin{array}{l}\text { Anthropology } \\
(\mathrm{n}=19)\end{array}$ & $\begin{array}{c}\text { Liberal Arts } \\
\text { and Sciences/ } \\
\text { Liberal Studies } \\
\quad(n=14)\end{array}$ \\
\hline ABCTE & $\begin{array}{l}\text { English Lang. } \\
\text { \& Literature } \\
\quad(\mathrm{n}=35)\end{array}$ & $\begin{array}{l}\text { Psychology } \\
(\mathrm{n}=10)\end{array}$ & & & \\
\hline $\begin{array}{l}\text { College Teaching } \\
\text { Experience }\end{array}$ & $\begin{array}{l}\text { Elementary } \\
\text { Teacher } \\
\text { Education } \\
(\mathrm{n}=17)\end{array}$ & $\begin{array}{l}\text { Psychology } \\
\quad(n=11)\end{array}$ & & & \\
\hline
\end{tabular}

Note: Statistics not reported when cell size is less than 10. Data are only available for graduates of public universities in Florida. 
Table 4 - Coursework Credit Hours by Alternative Pathway (All Certifications)

\begin{tabular}{|c|c|c|c|c|}
\hline & $\begin{array}{l}\text { Florida } \\
\text { Teacher } \\
\text { Preparation } \\
\text { Program } \\
\text { Graduates } \\
\text { [n=5485] } \\
\end{array}$ & $\begin{array}{l}\text { District } \\
\text { Alternative } \\
\text { Certification } \\
\text { Program } \\
{[\mathrm{n}=456]} \\
\end{array}$ & $\begin{array}{l}\text { Educator } \\
\text { Preparation } \\
\text { Institute } \\
{[n=63]} \\
\end{array}$ & $\begin{array}{l}\text { ABCTE } \\
{[n=15]}\end{array}$ \\
\hline $\begin{array}{l}\text { Coursework } \\
\text { Category }\end{array}$ & $\begin{array}{c}\text { Mean } \\
\text { (Std. Dev.) }\end{array}$ & $\begin{array}{c}\text { Mean } \\
\text { (Std. Dev.) }\end{array}$ & $\begin{array}{c}\text { Mean } \\
\text { (Std. Dev.) }\end{array}$ & $\begin{array}{c}\text { Mean } \\
\text { (Std. Dev.) }\end{array}$ \\
\hline All Education Coursework & $\begin{array}{c}62.99 \\
(22.60)\end{array}$ & $\begin{array}{c}3.53 \\
(8.51)\end{array}$ & $\begin{array}{c}2.13 \\
(5.04)\end{array}$ & $\begin{array}{l}1.20 \\
(2.73)\end{array}$ \\
\hline Education - Field-based & $\begin{array}{l}14.96 \\
(6.43)\end{array}$ & $\begin{array}{c}0.41 \\
(1.30)\end{array}$ & $\begin{array}{c}0.39 \\
(1.07)\end{array}$ & $\begin{array}{c}0.18 \\
(0.72)\end{array}$ \\
\hline Math Education & $\begin{array}{c}3.41 \\
(4.75)\end{array}$ & $\begin{array}{c}0.07 \\
(0.62)\end{array}$ & $\begin{array}{c}0.00 \\
(0.00)\end{array}$ & $\begin{array}{c}0.00 \\
(0.00)\end{array}$ \\
\hline Science Education & $\begin{array}{c}2.10 \\
(2.63)\end{array}$ & $\begin{array}{c}0.03 \\
(0.31)\end{array}$ & $\begin{array}{c}0.00 \\
(0.00)\end{array}$ & $\begin{array}{c}0.00 \\
(0.00)\end{array}$ \\
\hline Language Arts Education & $\begin{array}{c}8.37 \\
(6.30)\end{array}$ & $\begin{array}{c}0.38 \\
(1.26)\end{array}$ & $\begin{array}{c}0.04 \\
(0.37)\end{array}$ & $\begin{array}{c}0.00 \\
(0.00)\end{array}$ \\
\hline $\begin{array}{l}\text { English as a Second } \\
\text { Language (ESL) Education }\end{array}$ & $\begin{array}{l}2.31 \\
(2.94)\end{array}$ & $\begin{array}{c}0.07 \\
(0.67)\end{array}$ & $\begin{array}{c}0.00 \\
(0.00)\end{array}$ & $\begin{array}{c}0.20 \\
(0.77)\end{array}$ \\
\hline Math & $\begin{array}{c}5.66 \\
(7.66)\end{array}$ & $\begin{array}{c}4.95 \\
(6.57)\end{array}$ & $\begin{array}{c}5.83 \\
(5.16)\end{array}$ & $\begin{array}{c}6.50 \\
(9.88)\end{array}$ \\
\hline Statistics & $\begin{array}{c}1.43 \\
(2.16)\end{array}$ & $\begin{array}{c}1.82 \\
(2.35)\end{array}$ & $\begin{array}{c}2.04 \\
(2.47)\end{array}$ & $\begin{array}{c}1.37 \\
(1.98)\end{array}$ \\
\hline All Science Coursework & $\begin{array}{c}8.54 \\
(8.91) \\
\end{array}$ & $\begin{array}{c}15.39 \\
(21.29) \\
\end{array}$ & $\begin{array}{c}13.56 \\
(14.85) \\
\end{array}$ & $\begin{array}{c}30.92 \\
(35.78) \\
\end{array}$ \\
\hline Biology & $\begin{array}{c}3.16 \\
(4.82)\end{array}$ & $\begin{array}{c}6.55 \\
(11.41) \\
\end{array}$ & $\begin{array}{c}4.70 \\
(7.75) \\
\end{array}$ & $\begin{array}{c}15.39 \\
(19.91) \\
\end{array}$ \\
\hline Chemistry & $\begin{array}{c}1.64 \\
(3.64)\end{array}$ & $\begin{array}{c}4.05 \\
(7.57)\end{array}$ & $\begin{array}{c}3.85 \\
(6.51)\end{array}$ & $\begin{array}{c}8.57 \\
(11.43)\end{array}$ \\
\hline Physics & $\begin{array}{c}1.78 \\
(2.74)\end{array}$ & $\begin{array}{c}2.69 \\
(3.79)\end{array}$ & $\begin{array}{c}3.15 \\
(3.81)\end{array}$ & $\begin{array}{c}4.89 \\
(5.21)\end{array}$ \\
\hline Engineering & $\begin{array}{c}1.29 \\
(2.98)\end{array}$ & $\begin{array}{c}4.89 \\
(13.97)\end{array}$ & $\begin{array}{c}6.98 \\
(18.24)\end{array}$ & $\begin{array}{c}2.20 \\
(2.88)\end{array}$ \\
\hline English Literature & $\begin{array}{l}7.60 \\
(7.85)\end{array}$ & $\begin{array}{c}13.92 \\
(15.41)\end{array}$ & $\begin{array}{c}11.58 \\
(13.48)\end{array}$ & $\begin{array}{c}10.94 \\
(15.17)\end{array}$ \\
\hline $\begin{array}{l}\text { Credits Not in Educ., Math, } \\
\text { Stat., Sci., Eng., Health Sci. }\end{array}$ & $\begin{array}{c}49.09 \\
(26.87)\end{array}$ & $\begin{array}{c}89.92 \\
(30.26)\end{array}$ & $\begin{array}{c}96.76 \\
(29.27)\end{array}$ & $\begin{array}{c}76.30 \\
(43.36)\end{array}$ \\
\hline Arts & $\begin{array}{c}9.74 \\
(20.65)\end{array}$ & $\begin{array}{c}6.83 \\
(16.25)\end{array}$ & $\begin{array}{c}11.25 \\
(23.40)\end{array}$ & $\begin{array}{l}10.00 \\
(23.96)\end{array}$ \\
\hline Social Science & $\begin{array}{c}7.07 \\
(7.46)\end{array}$ & $\begin{array}{c}14.04 \\
(15.17)\end{array}$ & $\begin{array}{l}15.98 \\
(16.55)\end{array}$ & $\begin{array}{c}12.91 \\
(17.56)\end{array}$ \\
\hline Foreign Language & $\begin{array}{c}2.31 \\
(5.08)\end{array}$ & $\begin{array}{c}7.65 \\
(10.32)\end{array}$ & $\begin{array}{c}7.24 \\
(11.31)\end{array}$ & $\begin{array}{c}7.36 \\
(7.28)\end{array}$ \\
\hline Business & $\begin{array}{c}1.07 \\
(5.24)\end{array}$ & $\begin{array}{c}8.53 \\
(18.41)\end{array}$ & $\begin{array}{c}8.05 \\
(17.85)\end{array}$ & $\begin{array}{c}9.48 \\
(22.61)\end{array}$ \\
\hline
\end{tabular}

Note: sample includes only teachers with 100 or more known credit hours in university-designated courses taken in Florida public community colleges and universities prior to first year of teaching in Florida public schools. 
Table 5 - The Impact of Teacher Pathways on Student Achievement in Math and Reading, 2000/01 - 2009/10

[Teachers with 0-2 Years of Experience, Grades 4-10, Florida Preparation Program Completers are the Reference Group]
Math
Reading

\begin{tabular}{|c|c|c|c|c|}
\hline District Alternate Cert. & $\begin{array}{l}0.0251^{* *} \\
(0.0050)\end{array}$ & $\begin{array}{c}0.0104 * \\
(0.0052)\end{array}$ & $\begin{array}{l}0.0148^{* *} \\
(0.0046)\end{array}$ & $\begin{array}{c}0.0132 * * \\
(0.0051)\end{array}$ \\
\hline Educator Preparation Inst. & $\begin{array}{l}-0.0159 \\
(0.0127)\end{array}$ & $\begin{array}{l}-0.0409^{* *} \\
(0.0141)\end{array}$ & $\begin{array}{l}-0.0170 \\
(0.0110)\end{array}$ & $\begin{array}{l}-0.0280^{*} \\
(0.0112)\end{array}$ \\
\hline ABCTE & $\begin{array}{l}0.0783^{* *} \\
(0.0280)\end{array}$ & $\begin{array}{l}0.0641^{* *} \\
(0.0243)\end{array}$ & $\begin{array}{c}0.0162 \\
(0.0167)\end{array}$ & $\begin{array}{c}0.0198 \\
(0.0180)\end{array}$ \\
\hline School F.E. & Yes & No & Yes & No \\
\hline R-squared & $\begin{array}{r}0.665 \\
1370.037\end{array}$ & $\begin{array}{r}0.655 \\
1370.037\end{array}$ & $\begin{array}{r}0.608 \\
071040\end{array}$ & $\begin{array}{r}0.600 \\
071040\end{array}$ \\
\hline
\end{tabular}

Note: All models include time varying teacher and peer explanatory variables as well as indicators for each pathway (other than Florida preparation program completers). Standard errors adjusted for clustering at the teacher level are in parentheses.

${ }^{+}$significant at $10 \% ; *$ significant at $5 \% ; * *$ significant at $1 \%$. 
Table 6 - The Impact of Teacher Pathways on Student Achievement in Math and Reading, 2000/01 - 2009/10

[Teachers with 0-2 Years of Experience, Grades 6-10, Florida Preparation Program Completers are the Reference Group]

Math

Reading

\begin{tabular}{|c|c|c|c|c|}
\hline District Alternate Cert. & $\begin{array}{l}0.0263^{* *} \\
(0.0058)\end{array}$ & $\begin{array}{c}0.0103^{+} \\
(0.0061)\end{array}$ & $\begin{array}{l}0.0153^{* *} \\
(0.0053)\end{array}$ & $\begin{array}{c}0.0128 * \\
(0.0058)\end{array}$ \\
\hline Educator Preparation Inst. & $\begin{array}{l}-0.0205 \\
(0.0153)\end{array}$ & $\begin{array}{l}-0.0494 * * \\
(0.0162)\end{array}$ & $\begin{array}{l}-0.0168 \\
(0.0125)\end{array}$ & $\begin{array}{l}-0.0325^{* *} \\
(0.0124)\end{array}$ \\
\hline ABCTE & $\begin{array}{c}0.0775^{*} \\
(0.0315)\end{array}$ & $\begin{array}{c}0.0554^{*} \\
(0.0251)\end{array}$ & $\begin{array}{c}0.0157 \\
(0.0175)\end{array}$ & $\begin{array}{c}0.0194 \\
(0.0188)\end{array}$ \\
\hline School F.E. & Yes & No & Yes & No \\
\hline $\begin{array}{l}\text { R-squared } \\
\text { Number of Obs. }\end{array}$ & $\begin{array}{r}0.682 \\
944,337\end{array}$ & $\begin{array}{r}0.674 \\
944,337\end{array}$ & $\begin{array}{r}0.600 \\
688,551\end{array}$ & $\begin{array}{r}0.591 \\
688,551\end{array}$ \\
\hline
\end{tabular}

Note: All models include time varying teacher and peer explanatory variables as well as indicators for each pathway (other than Florida preparation program completers). Standard errors adjusted for clustering at the teacher level are in parentheses.

${ }^{+}$significant at $10 \% ; *$ significant at $5 \% ; * *$ significant at $1 \%$. 
Figure 1

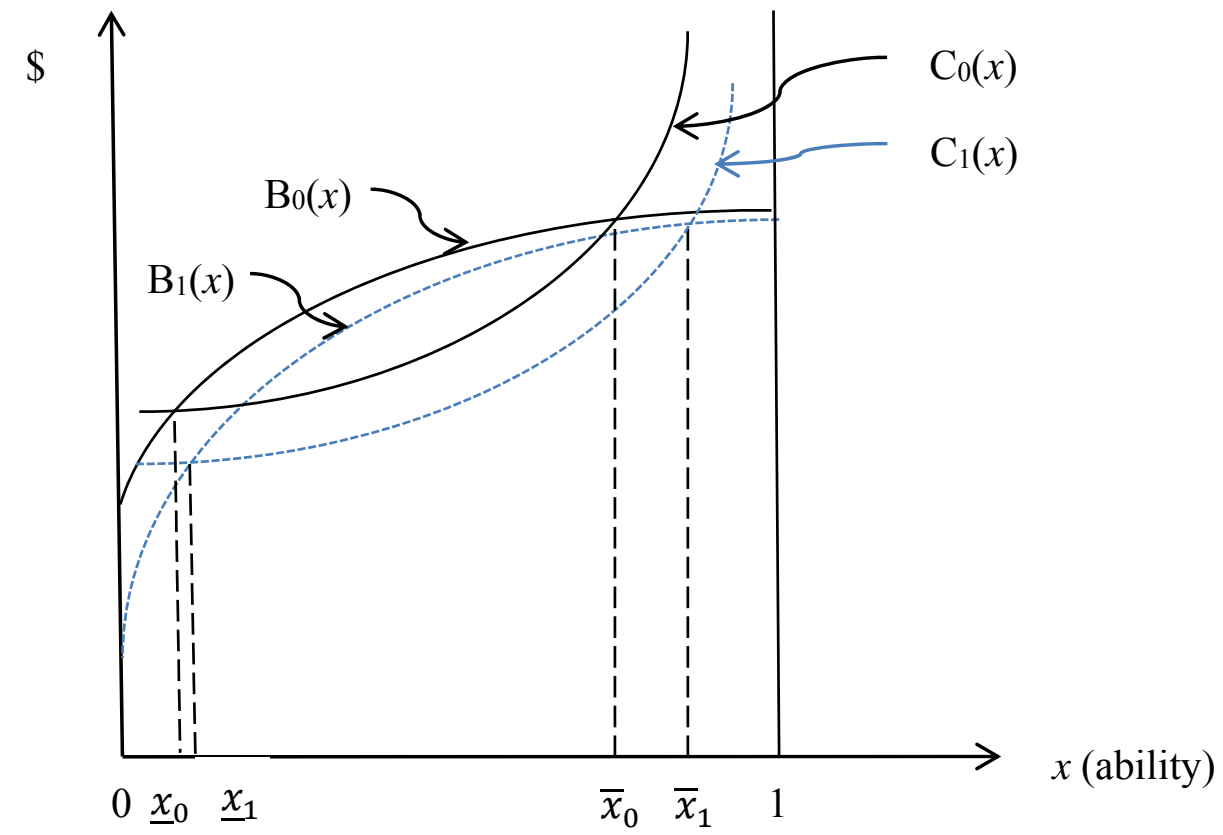


Figure 2 - Distribution of Estimated Teacher Effects by Pathway (Math - Model without School Fixed Effects)
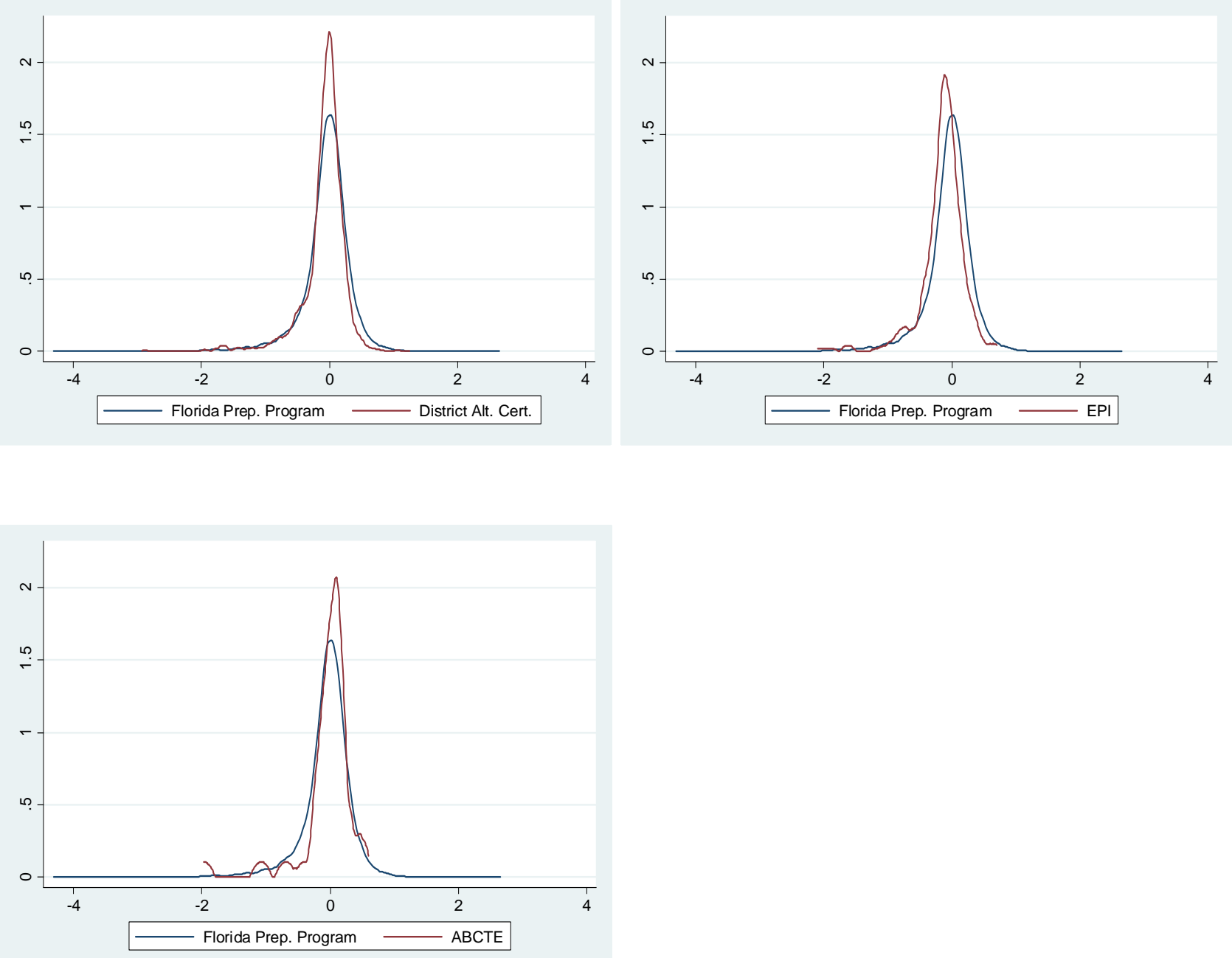
Figure 3 - Distribution of Estimated Teacher Effects by Pathway (Reading - Model without School Fixed Effects)
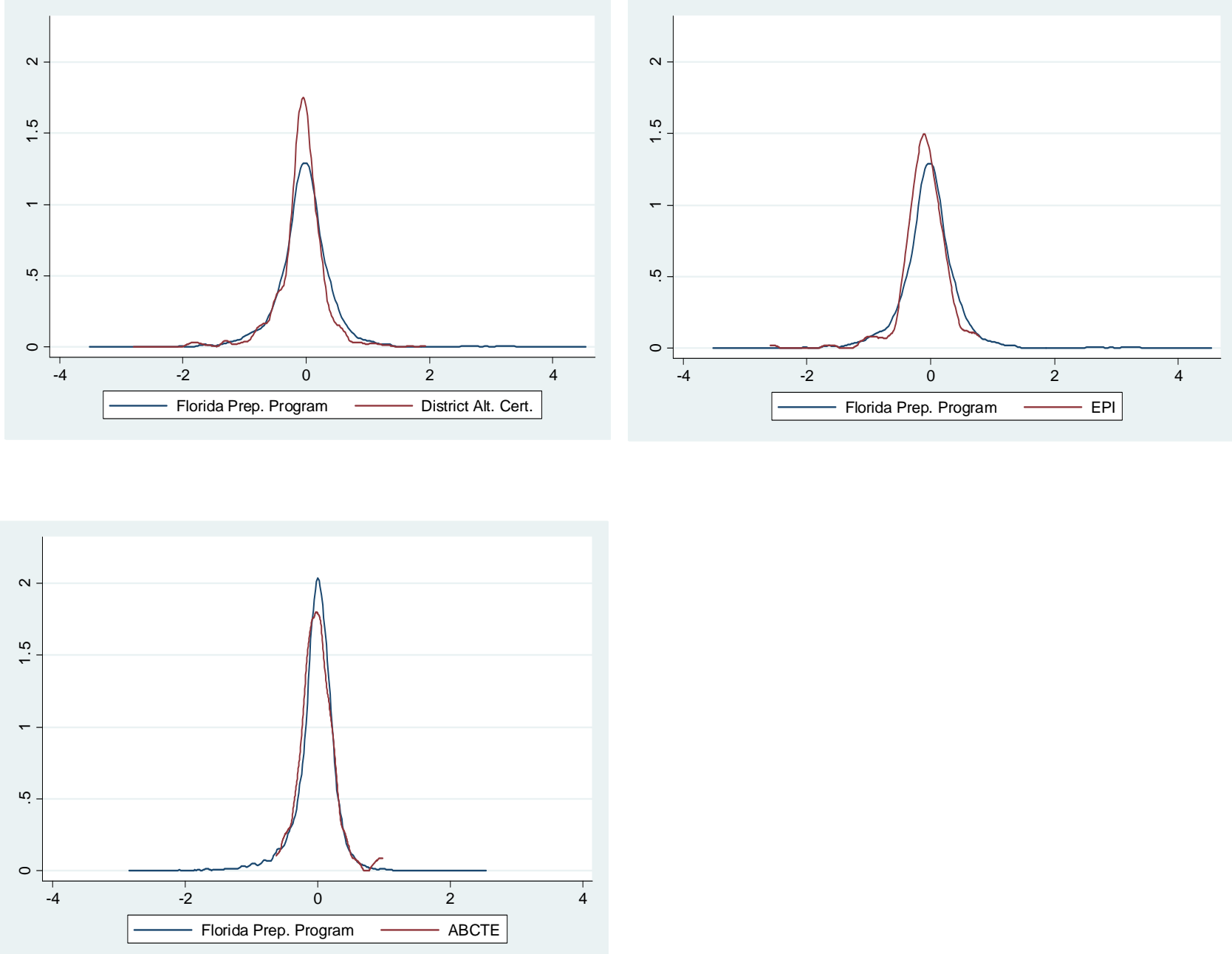